Juraj Šedivý

Bratysława

\title{
Terminologia opisu i analizy paleograficznej*
}

Klasyczna definicja każdej dyscypliny naukowej wymaga jasnego określenia przedmiotu, metod oraz celów. Wyniki badań powinny być weryfikowalne, co implikuje ich obiektywny charakter. Wymóg ten ma zasadnicze znaczenie dla odróżnienia nauki od sztuki. Elementem obiektywizacji każdej nauki jest ustalenie właściwej terminologii. Celem niniejszego artykułu jest krótkie zarysowanie międzynarodowych wysiłków nad wypracowaniem i upowszechnieniem spójnej terminologii oraz przegląd dotychczasowych słowackich badań paleograficznych, który prowadzi do projektu slowackiej terminologii paleograficznej. Terminologia ta powinna umożliwić opis i analizę pisma łacińskiego w różnych jego odmianach (jako pismo książkowe, dokumentowe i epigraficzne), pojawiającego się na naszym obszarze od czasów starożytnych aż do dnia dzisiejszego.

Paleografia jest nauką wizualną, co potwierdza powiedzenie, że „lepiej zobaczyć raz niż tysiąc razy usłyszeć czy przeczytać", ale czasem konieczne jest opisowe wyjaśnienie zjawisk paleograficznych. Niezbędne jest przy fachowej argumentacji paleograficznej, przy wypełnianiu podstawowych celów paleografii - przy ustalaniu tych samych bądź różnych rąk pisarskich, przy ustalaniu chronologicznego lub geograficznego pochodzenia pisma, a wreszcie przy ogólnej charakterystyce pisma i jego zmian, jako świadectw kultury piśmiennej danej epoki.

\section{Inicjatywy międzynarodowe}

Jakkolwiek najstarsze techniczne terminy paleograficzne istnieją od kilku stuleci (np. pismo „ksiażkowe” i „dokumentowe” zastosowal już Jean Mabillon, „majuskuła”, „minuskuła” $i$,kursywa” zostały wprowadzone przez Scipione Maffei), to przy czytaniu nawet najnowszej pracy specjalistycznej nadal napotykamy na mylące i mniej lub bardziej szczegółowe terminy. Praktyczna potrzeba współpracy międzynarodowej, jak też konieczność ściślejszej koordynacji większych projektów badawczych doprowadziła w połowie XX wieku do powstania Międzynarodowego Komitetu Paleografii Łacińskiej (Comité Inter-

\footnotetext{
* Dziękuję bardzo dr. Jerzemu Kaliszukowi z Warszawy za trud włożony w niewdzięczne zadanie dopasowania proponowanej terminologii slowackiej do wymogów języka polskiego. Tłumacz wykorzystał do tego celu terminologię wypracowaną razem z Edwardem Potkowskim i Jackiem Soszyńskim w ramach projektu Latin Palaeography Network.
} 
Juraj Šedivý

national de Paléographie Latine; w skrócie CIPL) ${ }^{1}$. Już na pierwszym kongresie międzynarodowym w Paryżu (1953) CIPL przyjął za jeden z pięciu celów głównych opracowanie jednolitej terminologii specjalistycznej.

Jak pisała czlonkini CIPL Herrad Spilling (Stuttgart), Comité International de Paléographie Latine zająl się poważnie kwestią terminologii zwlaszcza w latach siedemdziesiątych XX wieku. Rezultatem tej międzynarodowej inicjatywy było porozumienie dotyczące stworzenia sześciojęzykowego słownika terminów paleograficznych. Jako główny język wybrano francuski. Inicjatywa ta nie spotkała się jednak $z$ odpowiednim wsparciem instytucjonalnym i personalnym i dlatego słownik ten nie ukazal się do dnia dzisiejszego². Prawdopodobną przyczyną niepowodzenia całego projektu była chęć zawarcia w słowniku również całego ogólnego nazewnictwa pism (nazwy i definicje różnych stylów, gatunków i rodzajów) ${ }^{3}$

Część terminów paleograficznych znalazła się wreszcie w słowniku kodykologicznym, wydanym w 1985 roku przez Denisa Muzerelle'a z paryskiego Institut de Recherche et d'Histoire des Textes ${ }^{4}$. Na opracowaniu Muzerelle'a opieraja się niemal dosłowne przekłady: włoski i hiszpański, które ukazały się jako narodowe słowniki kodykologiczne ${ }^{5}$. Obecnie wszystkie trzy wersje językowe słownika Muzerelle'a są dosteppne przez internet, przy czym do większości terminów dodany jest odpowiednik angielski ${ }^{6}$. Paleografowie anglojęzyczni spotkali się w 2004 roku w celu stworzenia wspólnego angielskiego słownika paleograficznego, który jednak wciąż nie powstał.

Główną ideą wszystkich inicjatyw zmierzających do unifikacji jest nie tylko dopracowanie jednolitego jezzyka specjalistycznego, ale także doprecyzowanie terminów już używanych. Szczególnie często postuluje się, przynajmniej częściowe, ograniczanie używania różnego rodzaju określeń antropomorficznych (np. główka $e$ i $g$, brzuszek $b$ i $p$, nóżka, pätka, języczek litery $e$ itp.). Niektóre $z$ tych terminów są do tego stopnia utrwalone (np. laska), że trudno zastąpić je innym wyrazem. Według Herrad Spilling, konieczne jest najpierw uzgodnienie podstawowych elementów, które tworzą pismo, tzn. liczby i form gestów pisarskich oraz ich sekwencji, tak abyśmy $z$ doświadczenia wzrokowego czerpali jednoznaczne określenia ${ }^{7}$.

${ }^{1}$ Bardziej szczegółowo zob. Jií Prażák, Deset let Mezinárodniho paleografického komitétu, w: „Archivni časopis", 13:1963, z. 4, s. 241-243, ogólnie: Juraj Šedivý, Prehlad západoeurópskej latinskej paleografie stredovekého obdobia za posledné polstoročie, w: „Slovenská archivistika”, 38:2003, z. 1, s. 62-78.

${ }^{2}$ Herrad Spilling, Paläographische Perspektiven und terminologische Streiflichter, w: History of Latin Writing in the Carpatho-Danubian Region I, ed. Hana Pátková, Pavel Spunar, J. Šedivý, Bratislava - Praha 2003, s. 189-198.

${ }^{3}$ Albert Derolez, The publications sponsored by the Comité international de paléographie latine, ..Scriptorium", 58:2004, s. 110.

${ }^{4}$ Denis Muzerelle, Vocabulaire codicologique, Paris 1985.

${ }^{5}$ Marilena Maniaci, Terminologia del libro manoscritto. Préface di Denis Muzerelle, Roma - Milano 1996; Pilar Ostos, Maria Luisa Pardo, Elena Rodríguez, Versión española revisada y aumentada del Vocabulaire codicologique de Denis Muzerelle, Madrid 1997.

${ }^{6}$ Dostępne w: http://vocabulaire.irht.cnrs.fr/vocab.htm lub http://www.irht.cnrs.fr albo http://irht. cnrs-orleans.fr/cipl/CiplGen.htm.

${ }^{7}$ H. Spilling, Paläographische Perspektiven..., s. 192. 
Sytuacja w krajach mniejszych, jakim jest Slowacja, paradoksalnie jest łatwiejsza. Gdzie jest mniejsza liczba badaczy, tam łatwiej dochodzi do porozumienia. W 2002 roku powstała $z$ inicjatywy prasko-bratysławskiej akademicka sieć środkowo- i wschodnioeuropejskich paleografów i epigrafów pod nazwą Latin Palaeography Network, która gromadzi badaczy $z$ Niemiec, Polski, Łotwy, Rosji, Czech, Słowacji, Austrii, Węgier, Rumunii i Słowenii ${ }^{8}$. Jednym $z$ głównych rezultatów wspólnych warsztatów (w 2002 r. w Pradze, w 2003 r. w Bratysławie, w 2004 r. w Tepli) jest również projekt rzeczowego słownika paleograficznego. Głównym językiem jest niemiecki, terminy są podane również $w$ językach obszaru Europy Środkowej: czeskim, słowackim, polskim, rosyjskim, węgierskim i słoweńskim ${ }^{9}$. Słownik ukazał się w 2008 roku $^{10}$.

\section{Wstepne prace czeskie i slowackie}

W Słowacji, ze względu na bliskość języków, można było inspirować się terminologią czeską. Największy rozwój czeskich badań paleograficznych przypadł na lata od 60-tych do 80-tych XX wieku ${ }^{11}$. Bogactwo prac różnych autorów i w konsekwencji pojawienie się problemów terminologicznych doprowadziło do dyskusji na temat pojęć paleograficznych (w latach siedemdziesiątych XX wieku). Jaroslav Kašpar wstępnie zakończyl dyskusję projektem ogólnego slownika terminologicznego ${ }^{12}$. Projekt ten zawiera najbardziej dotychczas wszechstronny system nazewnictwa paleograficznego w Czechach, ale wprowadza niektóre terminy dyskusyjne (pismo „kreślone” zamiast minuskuły, różne znaczenie terminów kształt i forma pisma, nazwę majuskuła proponuje na określenie dwuliniowego pisma i wielkich liter, np. wersalików itp.).

Nie wszyscy w Czechach poslugiwali się terminologią Kašpara: autor najpopularniejszego podręcznika paleografii, Jindřich Šebánek, w odróżnieniu od A. Húščavu nie zawarl w swojej pracy odrębnego rozdziału o terminologii, lecz przy opisie wykorzystywał niektóre określone terminy bez podania bliższej charakterystyki (,otwarte a”, ,jednobrzuszkowe a”, „epsilonowe e”, „okragke r” lub „okrągle s”, ,laska” lub „nóżka”, ,pięta”, ,pętelka”, „rozszczepienie liter”) ${ }^{13}$. Milan Flodr, autor jednego $z$ nielicznych czeskich paleograficznych opracowań skryptoriów, przy opisach wspomagał się terminami "dukt”, „laska”, „pięta”, „łuk”, „brzuszek” (przy literze „a”), „pętelka”, ,wersaliki”, „długie s i f”, „okrągle s” itd. ${ }^{14}$

\footnotetext{
${ }^{8}$ Więcej informacji w: J. Šedivý, Akademická siet stredoeurópskych paleografov, „Slovenská archivistika", 39:2004, z. 1, s. 159-161.

${ }^{9} \mathrm{Nad}$ wariantem slowackim wraz z autorem pracowal również Prof. PhDr. Richard Marsina, DrSc.

${ }^{10}$ Vocabularium parvum scripturae Latinae, ediderunt J. Šedivý, H. Pátko-vá, Bratislava - Praha 2008.

${ }^{11}$ Przegląd badań czeskich na ten temat zob. J. Sedivý, Stredoveká latinská paleografia vo "východnej Európe” a medzinárodná paleografická spolupráca, „Slovenská archivistika”, 38:2003, z. 2, s. 78-97.

${ }^{12}$ J. Kašpar, Úvaha o paleografické terminologii, w: Acta Universitatis Carolinae. Philosophica et Historica 4-5. Z pomocných vèd historických 5-7, Praha 1987, s. 9-33.

${ }^{13}$ J. Šebánek, Základy pomocných vếd historických I. Latinská paleografie, 2. vyd., Brno 1971, s. 46, 55 , 61,62 .

${ }^{14}$ M. Flodr, Skriptorium olomoucké, Praha 1960, s. 52, 56, 72.
} 
Obecnie najwybitniejszą przedstawicielką mlodszego pokolenia czeskich paleografów jest Hana Pátková. W swoich albumach paleograficznych używa takich terminów, jak „,dukt”, „laska”, „łuk”, „pętelka”, „wielka litera”, „tzw. nogi słonia” („wąs"), ,jednobrzuszkowe a”, "rozszczepione $r$ z podwojoną laską" itd. ${ }^{15}$

Najstarszą poważną pracą poświęconą paleografii drukowaną $w$ języku stowackim jest niewątpliwie Pismo $i$ jego ewolucja Alexandra Húščavy ${ }^{16}$. W odrębnym rozdziale autor systematycznie opisuje zjawisko pisma (nazwy linii systemu czteroliniowego, charakterystyka majuskuły i minuskuły, podzial liter na krótkie, średnie i długie), jednak nie wyjaśnia terminologii związanej z konkretnymi kształtami liter. Używa jej jednak mimowolnie w swojej pracy, gdzie wprowadza takie terminy jak „belka”, „łuk”, „dolny łuk” lub „,brzuszek” (np. przy B), „góra” lub „głowa”, „chwościk” (kauda), ,języczek” (litery e).

Július Sopko, nestor słowackich kodykologów, przy opisie liter postępuje od charakterystyki ogólnych cech liter do opisu konkretnych ksztaltów. Używa terminów, które będą punktem wyjścia dla naszej propozycji (,laska”, „belka”, "wierzchołek”, „pięta”, „złączenie lasek"), ale niektóre nazwy antropomorficzne (,brzuszek”, „glówka”) i nieprecyzyjne (proste $r$ ) proponujemy zastapić innymi ${ }^{17}$. W pracach Richarda Marsiny dominuje argumentacja historyczna i dyplomatyczna, $z$ tego względu w jego tekstach terminy paleograficzne występują rzadziej (,ligatura”, „litera”, „pętla”, „brzuszek”, „kreski kończące”) ${ }^{18}$. Podręcznik paleografii autorstwa Jozefa Nováka pomyślany został jako czysto praktyczna pomoc w nauce czytania tekstów historycznych i dlatego nie znajduje się w nim odpowiedniej terminologii paleograficznej ${ }^{19} . Z$ brakiem spójnej słowackiej terminologii paleograficznej autor tego artykułu zmierzył się w ramach swoich prac naukowych, a słownik terminologiczny był częścią pracy magisterskiej i doktorskiej; recenzenci (P. Spunar, R. Marsina, J. Novák, J. Sopko, L. Sokolovski) nie mieli większych uwag do słownika ${ }^{20}$.

Ponieważ słowacka literatura paleograficzna jest uboga, możnaby częściowo inspirować się pracami z obszaru grafologii i pedagogiki pisania: Jozef Mistrík w swojej Grafologii wykorzystuje przyjęte podstawowe znaczenia jak „kreska” lub „linia”, „luk”, górne i dolne „laski”, ale czasami pojawiają się u niego terminy niety-

${ }^{15}$ H. Pátková, Cvičení z pozdnẽ středovèké paleografie, Praha 2001. Zob. również tej autorki Album pozdnè středovékého písma. Album scripturae medii aevi posterioris I-V, Praha 2002-2006.

${ }^{16}$ A. Húščava. Dejiny a vývoj nášho pisma. Bratislava 1951 (na temat terminów zob. np. 110-112. $157)$

${ }^{17}$ Zob. np. J. Sopko, O najstarších kódexoch so vztahmi ku územiu Slovenska, „Slovenská archivistika”, 21:1986, z. 2, s. 50-71.

${ }^{18}$ R. Marsina, Stúdie $k$ slovenskému diplomatáru I (= Historické śrudie 16, Bratislava 1974), s. 62, 69, 70. W pracach: Stridie $k$ slovenskému diplomatáru II, Bratislava $1989 \mathrm{oraz}$ Vývoj listinného písma v stredoveku na Slovensku, „Slovenská archivistika”, 26:1991, z. 1, s. 21-35 nie ma terminów odnoszących się do liter lub ich części.

${ }^{19}$ J. Novák, Paleografická č́tanka, Martin 2001.

${ }^{20}$ J. Sedivtý, Vývoj kniżného pisma na priklade rukopisov Bratislauskej kapituly, Iniedrukowana rozprawa na stopień naukowy] Bratislava 2002: tenże, Littera scripta manet. Vývoj nápisového písma na stredovekých a renesančných pamiatkach z územia dnešného Slovenska, [niedrukowana rozprawa na stopień naukowyl Bratislava 2005. 
powe jak „pazur”, „arkada”, „spojenie” (s. 147). Do celów dydaktycznych powstały prace Ludovíta Petránskeho i Boženy Šupšákovej, przy czym ten typ prac jest przez paleografów i historyków wykorzystywany $z$ wielkimi zastrzeżeniami ${ }^{21}$. Praca Boženy Šupšákovej o zjawisku pisma (pomyślana jako pomoc dydaktyczna przy nauce pisania w szkolach podstawowych) zawiera na przykład ogólny historyczny i teoretyczny wstęp, który jest pelen uproszczeń, a niektóre partie są pełne podstawowych blędów merytorycznych ${ }^{22}$. W pracy tej możemy spotkać się $z$ bardzo szczegółową, a również swojską słowacką terminologią („silne” i "słabe" kreski lub „pismo wstążkowe” zamiast międzynarodowego określenia „pismo z kontrastem linii włosowatych i grubych") ${ }^{23}$. Niektóre terminy, jak ,haczyk dolny”, „węzeł wężykowaty (falisty)” czy „węzel lewobrzeżny” przypominają raczej terminologię zapaśniczą niż paleograficzną. Ustalenia autorki pomóc mogą nauczycielom przy opisywaniu techniki pisma współczesnego, lecz przy opisie tekstów historycznych system ten jest nazbyt skomplikowany i niewłaściwy.

W przeciwieństwie do niektórych propozycji, które dążą do uchwycenia jak największej liczby szczegółów ${ }^{24}$, na następnych stronach przedstawiamy najbardziej przejrzysty system łatwych do zdefiniowania terminów. Będziemy się przy tym wzorować na terminach narodowych i czeskich, głównym zaś punktem wyjścia jest przygotowany słownik - dzieło akademickiej sieci Latin Palaeography Network ${ }^{25}$.

\footnotetext{
${ }^{21}$ L. Petranský, Písmo a obraz, Bratislava 1971; B. Šupšáková, Písané písmo v teórii a praxi, Bratislava 1996.

${ }^{22}$ Autorka twierdzi na przykład, że pismem anglosaskim jest uncjałka (sic!) następnie zależna od półuncjały (s. 15), że kuriała i pisma benewentańskie i montekasyńskie sa do siebie podobne (tamże), że „pismo slowiańskie”, określone jako „kościelny typ pisma” (jakby istniało jakieś świeckie), trwalo aż do końca XI w. (s. 19) itp. Stwierdzenie, że „szwabacha powstała w końcu XV wieku, fraktura zaś na początku XVI w." (s. 20) nie wymaga komentarza (fraktura to pismo z końca XV wieku, z którego drukarze wywiedli drukowaną szwabachę - wykluczone zatem, aby istniala „szwabacha pisana piórem szerokim”, jak uważa autorka na s. 21). Absolutnie nie do przyjęcia jest ilustracja nr 12 (s. 20) z podpisem „pismo czeskie XII wieku”. Nie dość, ̇̇e w XII wieku nie można mówić o jakimkolwiek „piśmie czeskim”, to ilustracja przedstawia mieszankę form wczesnogotyckich razem $z$ cyframi arabskimi, która w tym kształcie nie pojawia się w Czechach przed XV wiekiem! Na przedstawionej ilustracji ,j" pojawia się aż do połowy XVIII wieku. Rozbawienie wywoluje zdanie, że pólkursywa humanistyczna pojawiła się na dworze Macieja Korwina (1458-1490), od polowy zaś wieku XV „także u nas" (s. 20).

${ }^{23}$ Autorka wprowadza swoją „uczoną" terminologię na str. 31-34 a 120-129.

${ }^{24}$ Na przykład cytowana praca B. Sup̌ákovej czy nieco zbyt szczególowy slownik: Deutsche Inschriften: Terminologie zur Schrifteschreibung, Hg. von den Mitarb. der Inschriftenkommission der Akad. der Wissenschaften in Berlin etc., Wiesbaden 1999.

${ }^{25} \mathrm{~W}$ ostatecznej formie słownika uczestniczyli wszyscy członkowie LPN, inicjatorami i twórcami koncepcji byli szczególnie H. Pátková, Jiři Roháček i J. Šedivý.
} 


\section{Terminologia paleograficzna}

$Z$ punktu widzenia klasyfikacji możemy dla każdego pisma ustalić okres historyczny, styl, rodzaj i typ. Okres historyczny to czas istnienia w rozwoju kultury piśmiennej, która charakteryzuje się podobnymi warunkami społecznymi i kulturowymi. Jako okres historyczny w rozwoju łaciny możemy wyznaczyć na przyklad czas kształtowania pisma lacińskiego (VI w. p.n.e. do II w. p.n.e.), okres górnorzymski (II w. p.n.e. do III w. n.e.), późny antyk (III-V/VI w.), okres partykularyzmu znany jako okres tzw. pism szczepowych (VI-VIII/XII w.), okres karoliński i pokaroliński (VIII-XII w.), okres gotyku (XII-XV w.), okres nowożytny (po wynalezieniu i upowszechnieniu druku).

W granicach samego okresu historycznego możemy, według propozycji Jiřiego Pražáka, wyróżnić różne style i typy (warianty) ${ }^{26}$. Jakkolwiek przy definicji okresu historycznego wychodzimy $z$ uwarunkowań społecznych, w jakich rozwijała się kultura piśmienna danej epoki, styl pisma określany jest przez konkretną formę pisma w ramach danego okresu historycznego. Przedstawia on zestaw cech ogólnych znaków piśmienności w konkretnym czasie. Na przykład w ramach okresu partykularyzmu spotykamy się ze stylem insularnym (iryjskim i anglosaskim), stylem merowińskim czy wizygockim. W okresie nowożytnym możemy wyróżnić dwa główne style: humanistyczny i neogotycki. W wypadku, gdy w ramach niektórych okresów doszlo do wytworzenia jednolitego „ogólnoeuropejskiego stylu", nazwy niektórych okresów historycznych i stylów w nich występujących mogą się pokrywać (np. okres i styl gotycki).

Nazwa rodzaju (niem. Schriftart) pisma (druh pisma) oznacza zamkniętą grupę w ramach stylu, charakteryzującą się tymi samymi cechami - zarówno określonym sposobem zapisu, jak i jednakowymi ksztaltami grafemów (np. w ramach stylu gotyckiego rozpoznajemy trzy główne rodzaje: minuskułę gotycka, bastardę i kursywę). Wreszcie typ pisma oznacza terytorialną, regionalną lub lokalną specyficzną grupę w ramach określonego rodzaju (np. rotunda obejmuje terytorialny wariant minuskuły gotyckiej, używany głównie na obszarze dzisiejszych Włoch i południowej Francji; pokarolińska minuskula w przeciwieństwie do stylu okrąglego jest regionalnym wariantem używanym w części górnoniemieckiej; pismo zwane littera Parisiensis albo minuskulą prekarolińską z klasztoru żeńskiego w Chelles możemy uznać za lokalne typy). Typy (warianty) pisma można również określić na podstawie poziomu stylizacji zapisu. Ogólnie możemy w ramach określonych rodzajów pisma rozpoznać typ kaligraficzny (starannie pisane $\mathrm{i}$ „malowane” pismo), typ podstawowy (normalny poziom zapisu) i typ pospieszny (szybszy zapis z tendencją do upraszczania „normalnych” tzn. ustalonych ksztaltów) ${ }^{27}$.

${ }^{26}$ Zob. Jiří Pražák, Názvosloví kniżnich písem v českých zemích I. 11.-13. stoleti, „Studie o rukopisech”, 4:1965, s. 1-27 (o triadzie styl, rodzaj, typ - štýl, druh, typ s. 8-9).

${ }^{27} \mathrm{~W}$ piśmie gotyckim wprowadzony został podział według stylizacji na: formata (najstaranniejsze), libraria, currens (najmniej staranne). Ze względu na to, że między typami nie istnieją ostre granice, ich oznaczenie jest często subiektywne i traktujemy je tylko pomocniczo. 
Według sposobu użycia możemy pisma łacińskie podzielić na pismaksiążkowe (lub kodeksowe), pisma dokumentowe (lub dyplomatyczne) oraz pisma inskrypcyjne (lub epigraficzne). Oznaczenie „pismo książkowe” w pracach słowackich jest wykorzystywane i nie ma potrzeby przedstawiać go bardziej szczególowo. Stylistycznie lepiej jest określać je synonimem „pismo kodeksowe”, gdyż termin ten trafniej oddaje istote zjawiska. Oznaczenie „kodeks” jest terminem technicznym na książkę rękopiśmienną okresu starożytności i średniowiecza, podczas gdy termin bardziej ogólny „książka” może być wiązany z pismem księgi urzędowej lub drukowanej.

Określenie „pismo dokumentowe” jest kalką, pochodzącą z niemieckiego obszaru językowego (Urkundenschriff), podobnie jak ekwiwalent francuski (écriture diplomatique). Wadą tego określenia jest to, że jako pisma „dokumentowe” oznaczamy pisma listów, ksiagg urzędowych i innych kategorii dyplomatycznych. Byłoby zatem lepsze określenie „pismo dyplomatyczne”, którego pole semantyczne jest szersze. W konsekwencji utrwalonej konwencji językowej, pojęcie „pisma dokumentowe” oznacza wszelkie pisma w całej dyplomatyce, dlatego te $\dot{z}$ proponujemy w tym wypadku stosować wariant tradycyjny.

Należy skorygować twierdzenie Aleksandra Húščavy, że „dukt pisma dokumentów jest swobodniejszy, kształt liter różny, a pismo bez wątpienia nosi znamię spontaniczności"28. Wystarczy porównać kaligraficzną gotycką minuskułę dokumentową Beli IV i prawie nieczytelną kursywę książkową w kronice bratysławskiej. W obu kategoriach - pisma książkowego i dokumentowego - mamy do czynienia $z$ bliskimi gatunkami, które w niektórych okresach różnią się nie tyle odrębnymi kształtami, co ogólnym ukladem (layout) i celem. Szczególnie w okresach przełomów (jak np. drugi trymestr XIII wieku lub koniec XIV wieku na Węgrzech) wyraźne są wzajemne wpływy; niekiedy pismo ksiązkowe pojawialo się $\mathrm{w}$ dokumentach i odwrotnie.

Do pisma inskrypcyjnego (epigraficznego) tradycyjnie zaliczane są wszystkie teksty na innym materiale niż paleograficzny (papirus, pergamin, papier). Podobnie tradycyjnie podkreślana jest różnica między tym pismem $z$ jednej strony a pismem ksiażkowym i dokumentowym $z$ drugiej. Nie jest to prawda! Interakcje między pismem książkowym (rzadko dokumentowym) a epigraficznym są, $z$ punktu widzenia genezy, ewidentne: w okresie najstarszym pismo książkowe i dokumentowe wywodziło się z epigraficznego, a i później ksztalty wersalików inspirowane były podobnymi w piśmie epigraficznym. $Z$ drugiej strony, niektóre pisma napisowe pochodza ewidentnie $z$ pisma książkowego (np. epigraficzna minuskuła gotycka). Kształt niektórych pism książkowych i epigraficznych może być jednakowy (np. minuskuła gotycka książkowa i epigraficzna około $1400 \mathrm{roku})^{29} . Z$ praktycznego punktu widzenia podział pism ze względu na funkcje książkowe, dokumentowe i epigraficzne jest ogólnie akceptowany, jednak trzeba być świadomym określonych słabości teoretycznych tego podziału.

\footnotetext{
${ }^{28}$ A. Húščava, Dejiny..., s. 111.

${ }^{29} \mathrm{O}$ rozwoju pism epigraficznych na terenie Europy Środk. zob. J. Šedivý, Ukryté v písme. K datovaniu stredovekých pamiatok na základe ich nápisov, „Byzantinoslovaca”, 1:2006, s. 244-252.
} 
W niektórych okresach historycznych, obok podstawowego pisma na „dobrym poziomie”, możemy znaleźć pisma niezwykle kaligraficzne, ale również odwrotnie indywidualne zapisy. Według $\mathrm{k} \mathrm{r} \mathrm{y} \mathrm{te} \mathrm{ríó} \mathrm{e} \mathrm{s} \mathrm{t} \mathrm{e} \mathrm{t} \mathrm{y} \mathrm{c} \mathrm{z} \mathrm{n} \mathrm{y} \mathrm{c} \mathrm{h}$ możemy wówczas mówić o trzech typach estetycznych - najniższym (pospieszne pismo codziennych notatek i wpisów), średnim (podstawowe pismo „pospieszne”) i najwyższym (pismo kaligraficzne, zaprojektowane ze szczególną starannościa). Podobny podział zaproponowal Gerard I. Lieftinck w ramach swojego konsekwentnie zdefiniowanego systemu pism gotyckich (currens, libraria, formata) ${ }^{30}$. Paleografia słowacka (J. Sopko) przejęla nazwy Lieftincka, ale niekonsekwentnie zaproponowane przezeń definicje, co może, ze względu na terminologię wspólczesnych podręczników (B. Bischoff, K. Schneider), przysparzać trochę zamieszania. Sklaniam się więc do oznaczeń slowackich: estetyczny typ pośpieszny, podstawowy wspólny, kaligraficzny (estetický typ zbeżný / jednoduchý (bežný) / kaligrafický). W praktyce zaliczamy do typu kaligraficznego te pisma, które odznaczają się bardzo starannym wykonaniem, bardziej „malowaniem” niż pisaniem (np. w minuskule gotyckiej wynikiem jest konsekwentnie oddzielne pisanie poszczególnych liter, konsekwetne lamanie lasek oraz obecność kresek włosowatych i grubych). Na przeciwnym biegunie znajduje się typ pospieszny, który oznacza pismo spisane bez starania o jakikolwiek efekt estetyczny, przeznaczone zwlaszcza na użytek osobisty. Przy pospiesznej minuskule gotyckiej chodzi na przykład o pismo tylko $z$ oznakami łamania, często $z$ wcięciami przechodzącymi aż do spojenia lasek. Pospieszna kursywa gotycka jest pismem trudno czytelnym, zwykle $z$ bardzo szybkim zapisem, w którym dochodzi do uproszczenia i przekształcenia podstawowych kształtów. Kursywa kaligraficzna przeciwnie w swoim dukcie i kształtem bliższa jest bastardzie.

$Z$ punktu widzenia wpływu indywidualności pisarza na charakter ogólny pisma i kształty poszczególnych liter, pisma możemy podzielić na kanoniczne $i$ indywidualne. Pierwsza grupa przeważa w okresach charakteryzujących się niskim stopniem alfabetyzacji i wyraźnym wpływem nielicznych ośrodków kultury piśmiennej (np. Europa środkowa do XII wieku). Pisma indywidualne przeważają w spoleczeństwach $z$ wysokim stopniem znajomości pisma, gdzie pismo jest obecne w praktyce codziennej wszystkich warstw społecznych (np. obszar Italii w późnej starożytności czy obecna Unia Europejska). Podobnie jak określenie typów estetycznych, tak i charakterystyka paleograficzna stopnia zindywidualizowania ręki pisarskiej jest w znacznym stopniu subiektywna, a ocena, na ile rękopis różni się od ogólnie uznanego kształtu (kanonu), jest w pewnym stopniu indywidualna ${ }^{31}$.

Z punktu widzenia wartości semantycznej możemy pisma hierarchicznie podzielić na dwie podstawowe kategorie - pismo tekstowe i wyróżnione ${ }^{32}$. Dru-

\footnotetext{
${ }^{30}$ B. Bischoff, Gerard I. Lieftinck, Giulio Batelli, Nomenclature des écritures livresques du IX au XVI siécle, Paris 1954 (Colloques internationaux du CNRS. Sciences humanines 4), s. 15-33.

${ }^{31}$ Czasami ilustracja w zalączniku jest jedyną możliwością obiektywnego opisu.

${ }^{32}$ Najlepszym niemieckim odpowiednikiem może byc் wyraz Auszeichnungsschrift; w języku angielskim autorzy najczęściej posługują się terminem display script.
} 
ga, hierarchicznie wyżej postawiona kategoria może być wyrażona na wiele sposobów - podkreśleniem, użyciem różnego modułu ${ }^{33}$, koloru ${ }^{34}$, innego kroju lub typu pisma ${ }^{35}$ czy zdobieniem. Pismo ozdobne ${ }^{36}$ może mieć trzy podstawowe formy: ozdobione litery, pisarskie inicjałki i inicjały. Litery ozdobione - zarówno majuskuła jak i minuskuła - można scharakteryzować jako najprostsze formy zdobienia tekstu. Litery takie nie różnią się od pisma tekstu wielkością, lecz prostym sposobem ozdobienia - np. przekreśleniem (często innym kolorem niż tekst podstawowy - zwłaszcza czerwonym), zakreśleniem itp. Zdobienia takie mogą występować samodzielne lub tworzyć krótszą serię, czyli całe słowa lub krótki tekst. Powstają one zwykle bezpośrednio przy pisaniu tekstu głównego, rzadko są wytworem pracy późniejszego komentatora czy czytelnika.

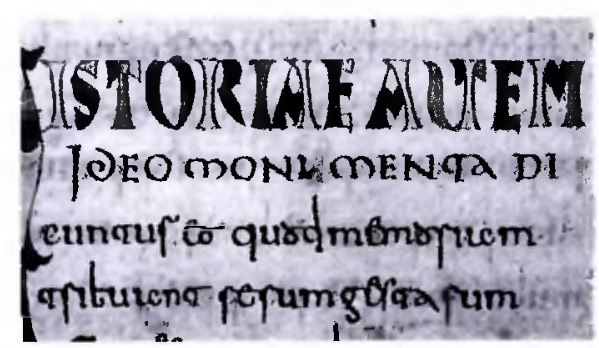

Fot. 1: Przedstawienie hierarchii pism za pomocą różnych krojów liter.

W pierwszym wersie znajduje się grupa inicjalów.

${ }^{33}$ Typowym średniowiecznym przykladem jest zastosowanie specjalnie stylizowanych liter elongata albo litterae elongatae na początkowe lub końcowe formuły wczesnośredniowiecznych dokumentów. Pod względem ksztaltu elongata może być kombinacją form różnego pochodzenia (z kapitały majuskulnej lub uncjały, minuskulnej kursywy merowińskiej, karolińskiej albo minuskuły dyplomatycznej).

${ }^{34} \mathrm{~W}$ średniowieczu najczęściej spotykanym wyróżnieniem kolorystycznym jest rubrykacja, tzn. użycie czerwonego koloru w części tekstu. Rzadko spotykamy chryzografį̨, tzn. użyciem metalu (złoto, srebro). Również rzadko do odróżnienia od pisma tekstu używane były inne farby (np. biel na kolorowym podkladzie w iluminowanych partiach Ewangeliarza wyszehradzkiego.

${ }^{35}$ W okresie karolińskim była np. ogólnie akceptowana hierarchia skryptorium w Tours: 1) Capitalis quadrata, 2) Uncialis, 3) Capitalis rustica, 4) Semiuncialis, 5) Minuscula Carolina. Do tej kategorii możemy dołączyć też używanie kapitalek (liter wywodzonych z kapitały, ale wielkością równych tekstowi głównemu, zapisanemu zwykle w minuskule dyplomatycznej) do zapisu nazw własnych w dokumentach XI i 1 połowy XII wieku.

${ }^{36}$ Jako nawiązanie do niemieckiego odpowiednika Schmuckschrift albo Zierschrift przychodzą nam na myśl dwa słowackie warianty - pismo zdobené albo písmo ozdobné (pismo zdobione a. ozdobne). Wolimy termin zdobené, ponieważ zakłada intencję, zamierzone zdobienie, z drugiej strony pismo ozdobné (tj. posiadające szczególny walor estetyczny) może być używane jako kaligraficzne pismo tekstowe i wiazzane raczej $z$ subiektywną oceną obserwatora. 


\section{aef. Mutir luarf \\ duo mutir lucur. \\ noctans dus. Iuci}

Fot. 2: Ozdobione wersaliki M i L.

Wyższy poziom zdobienia pisma stanowią inicjałki pisarskie. W odróżnieniu od inicjałów są one w większości dzielem samego pisarza. Inicjałki pisarskie mogą mieć kształt powiększonych wersalików, często innego koloru niż tekst główny, które jednak różnią się od inicjałów mniejszym rozmiarem i skromniejszym zdobnictwem. W ramach tej kategorii można wyróżnić zdobienie zdania wersalikami (ozdobione pierwsze litery zdania, które są podstawowym zdobieniem, różniącym się wielkością od innych form wersalików) oraz bardziej wyodrębniony wersalik inicjałowy (stojący na początku wiersza i wyraźniej odróżniony od tekstu głównego). W okresie gotyku rozróżniamy według tych kryteriów kadelę ( $k a d e l u$ ) (wersalik wielkości dwóch wierszy zapisany takim samym atramentem co tekst glówny) i lombard (inicjalek - słow. lombarda) (wersalik inicjalny wyróżniony innym kolorem, zwlaszcza czerwonym lub niebieskim).

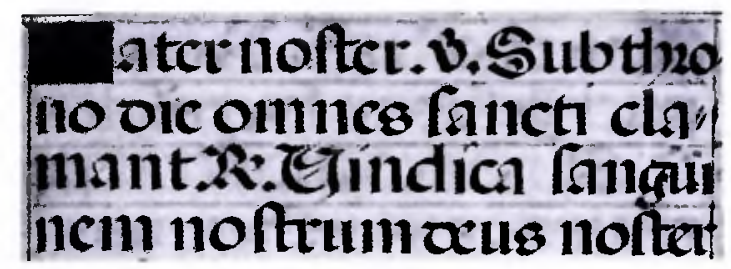

Fot. 3a i 3b: Wersaliki inicjalowe $P$ (ater) i zdobione wersaliki zdania $S(u b)$ i $U($ indica).

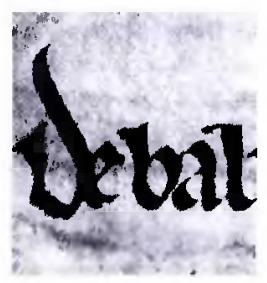

Fot. 4a: Kadela tzn. ozdobny wersalik gotycki $D(e)$. 


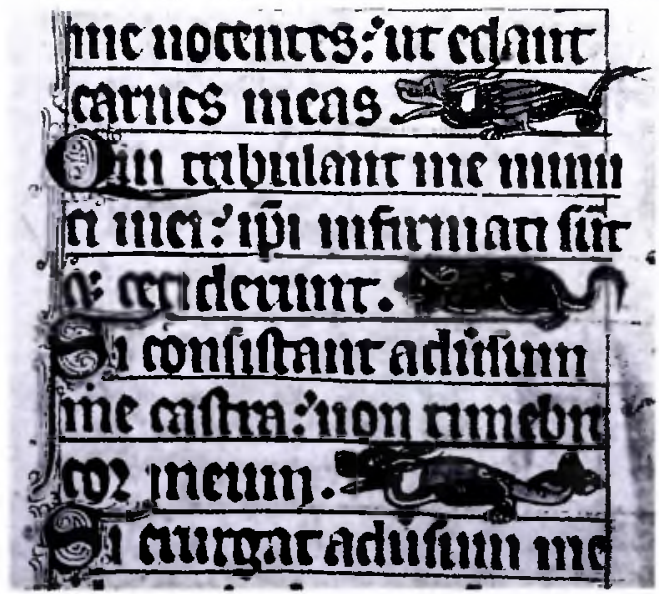

Fot. 4b: Lombardy gotyckie $Q(u i)$ i $S(i)$ ozdobione za pomocą kwiatonów i przykład wypełnienia niezapisanego miejsca w wierszu (stwory fantastyczne).

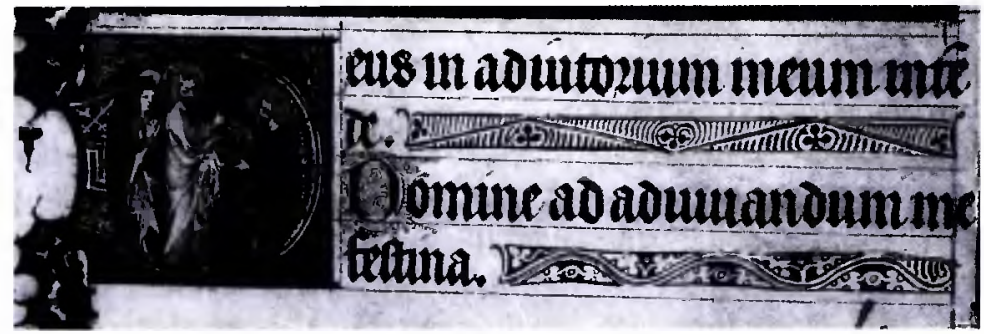

Fot. 5: Inicjał (historyzowany) D(eus).

Najbardziej ozdobnym elementem dekoracyjnym pisma jest inicjał, tzn. litera, stojąca zwykle na początku calego tekstu lub jego szerszej części, wyróżniona wielkością i ksztaltem. Często towarzyszy jej dekoracja antropomorficzna, zoomorficzna lub floraturowa. W wypadku gdy znajdują się w niej lub na niej sceny rodzajowe $z$ postaciami ludzkimi mówimy o inicjale historyzującym. Szczególnie w XIV stuleciu inicjały (rzadko również inicjałki pisarskie) występują $z$ floraturą (od franc. fleuronée - ukwiecenie), tzn. linearnym ornamentem piórkowym $\mathrm{z}$ perelkami, pąkami lub palmetami ( $\mathrm{z}$ rdzeniem lub bez) i wiciami ${ }^{37}$. Rzadko w tekstach pojawiają się grupy inicjalów (typowe we wczesnym średniowieczu - fot. 1). Inicjały są zazwyczaj dzielem specjalisty - iluminatora - i przygotowywane są po zapisaniu calego kodeksu lub dokumentu. $Z$ powodu tego podziału prac na przyklad pisarze w gotyku zostawiali miejsce na przyszły inicjal. W miejscu tym

\footnotetext{
${ }^{37} \mathrm{O}$ zdobieniu pisma zob. np.: Christine Jakobi-Mirwald, Buchmalerei: ihre Terminologie in der Kunstgeschichte, wyd. 2, Berlin 1997, zwlaszcza s. 40-89; taż, Die Auszeichnungsschriften in mittelalterlichen Codices. Ein terminologisches Problem, w: Methoden der Schriftbeschreibung, hrsg. von Peter Rück, Stuttgart 1999, s. 107-117. W ostatniej pracy autorka podaje ewolucje poglądów od czasów powojennych do współczesności.
} 
zapisywali jednak drobnym pismem (zwykle kursywą gotycka) reprezentant, tzn. literę, która ma być przedstawiona w tym miejscu przez iluminatora. Jako nawiązanie do pisma zdobionego możemy dostrzec proste pismo tekstowe.

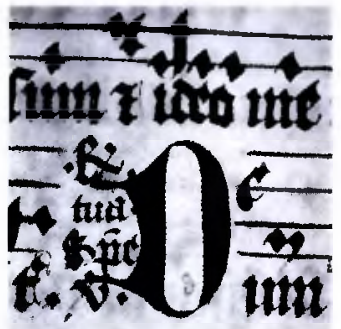

Fot. 6: Drobny reprezentant (kursywne $d$ ), który nie został zakryty niebieskim lombardem $D(u m$ ).

Ze względu na układ pisma w ramach systemu czteroliniowego, dzielimy pismo na dwuliniową majuskute (która może mieć formy kapitałkowe, uncjalne, kursywne lub mieszane) oraz czteroliniową minuskutę. W pierwszej grupie rozróżniamy wersaliki (niem. Versalien - tekst zapisany wyłącznie majuskułą) i kapitatki. Kapitałki (niem. Kapitälchen) są również pismem majuskulnym (dwuliniowym), ale wielkością zajmują przestrzeń między minuskułą tekstową i majuskuła, a nawet są tak wysokie jak minuskuła innego tekstu. Kształt liter pochodzi prawie wyłącznie $z$ kapitały, a w starszej formie minuskuły dyplomatycznej często używano jej do zapisu imion własnych.

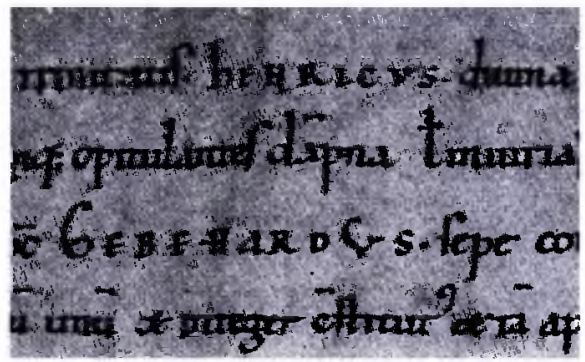

Fot. 7: Kapitałki równe wielkością minuskule (Henricvs).

Pismo można opisać w przestrzeni wyznaczonymi liniami, które fikcyjnie określają (ograniczaja) grafemy. Już A. Húščava uznał podstawową i górną linię (przy majuskule) lub skrajna, górna, podstawowa i dolnq linię (między nimi górny, podstawowy i dolny pas). Litery wpisane w pas średni możemy scharakteryzować jako krótkie (np. $a, e, i, o$ ), występujące w dwóch pasach jako średnie (np. $b, d, g, p$ ) oraz występujące we wszystkich trzech pasach jako długie (np. flub długie $s)^{38}$. Części liter znajdujące się $\mathrm{w}$ górnym pasie oznaczamy jako laski górne, a w dolnym pasie jako laski dolne.

${ }^{38}$ A. Húščava, Dejiny..., s. 110-111. Przeciwnie Kašpar, Úvaha.., s. 17) mówi o podstawowej, środkowej, górnej i dolnej linii. 


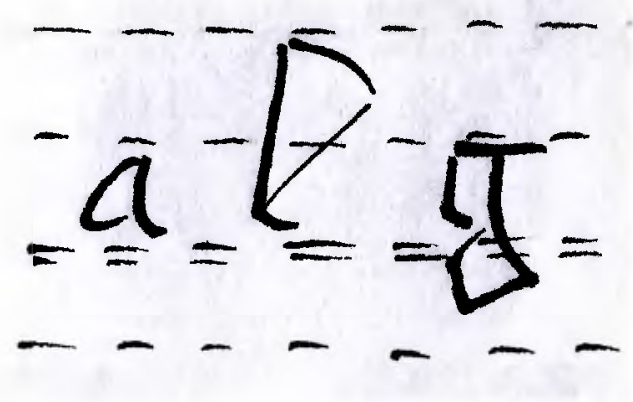

Fot. 8: Skrajna. górna. podstawowa i dolna linia określające pasy: górny, podstawowy i dolny.

Laski (kreski) mogą być stojące, a górna lub dolna kreska może się zwężać, rozszerzać lub być regularna. $\mathrm{W}$ wyniku techniki pisania dominuje zwężenie w dolnych laskach (np. typowe sztyletowe zwężenie dolnej laski minuskuły insularnej) i odwrotnie, górne laski mogą się rozszerzać (maczugowato jak we wczesnej minuskule karolińskiej lub klinowato jak w półuncjale insularnej). Następnie kreska może być wygięta, rozszczepiona lub zakończona pętelką (gest pętelki skierowany jest przeciw gestowi wychodzącemu $z$ laski - np. kaligraficzna kursywa gotycka dokumentowa typu Trecento I). Ostatnią możliwością tworzenia górnej kreski jest jej zakończenie pętelką (kontynuacja ruchu wychodzącego $z$ laski litery w tym kierunku, typowe dla kursywy gotyckiej, neogotyckiej lub humanistycznej). W starszych formach minuskuły dyplomatycznej (lub kurialnej) typowe są nadzwyczaj wydłużone górne kreski zakończone (pół)ósemką lub beta-pętelką.

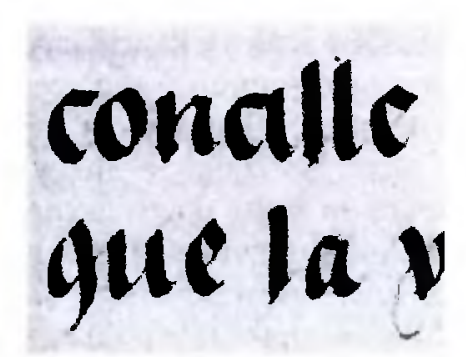

Fot. 9a: Górne laski mogą być zakończone tępo.

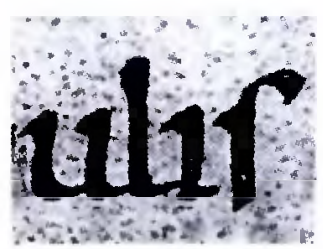

Fot. 9b: Górne laski rozszerzone.

Z badań nad książką i księgozbiorami historycznymi, 3:2009 


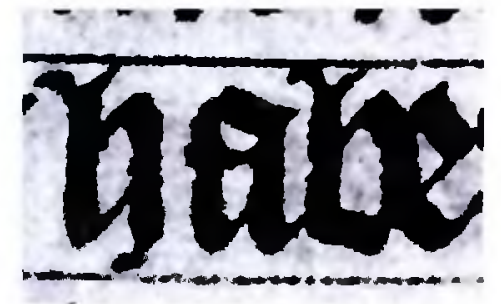

Fot. 9c: Górne laski rozszczepione.
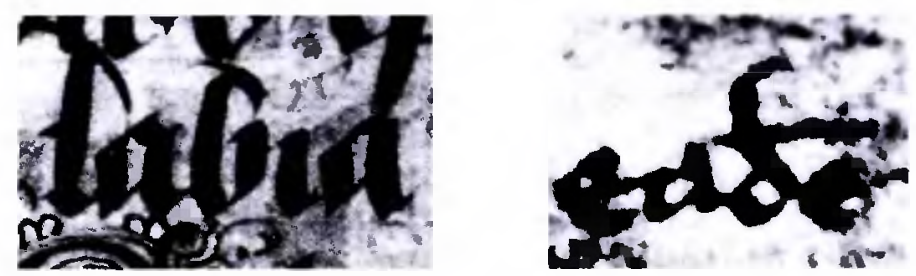

Fot. 9d: Górne laski zakończone niepełną pętelką.

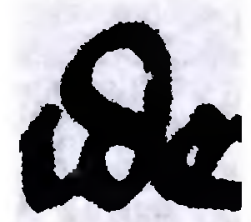

Fot. 9e: Górna laska zakończona pętelką właściwą.

W analizie pisma (np. w analizie praktyk kancelaryjnych lub w porównaniu rąk pisarskich) należy postępować od najogólniejszych cech do szczegółowego opisu poszczególnych form. Jako jedną z cech ogólnych opisujemy zwierciadło tekstu (niem. Schriftspiegel), tzn. rozmieszczenie tekstu w ramach całego materiału pisarskiego (karty, dokumentu, nośnika epigraficznego). Może ono przybierać różne formy: np. prosty jednokolumnowy tekst, dwukolumnowy tekst - ewentualnie $\mathrm{z}$ międzywierszowymi (interlinearnymi) lub okalającymi (marginalnymi) glosami (komentarzami, dopełnieniami lub poprawkami do głównego tekstu, zwykle pisanymi pismem mniejszych rozmiarów niż tekst główny). W opisie zwierciadla strony należy mieć na uwadze liczbę kolumn i wierszy, obecność reklamantów i kustoszy albo rodzajów nagłówków (np. w księgach biblijnych). Reklamanty i kustosze oznaczaja właściwą kolejność składek rękopisu. Jako reklamant rozumiemy pierwsze słowo (słowa) $z$ następnej składki umieszczone w prawym dolnym rogu verso ostatniej karty poprzedniej składki; kustosz jest liczbowym odwołaniem kolejności danej składki w ramach calego rękopisu - zwykle w formie liczby rzymskiej lub arabskiej znajduje się na środku verso ostatniej karty każdej składki. Nad kustoszem zazwyczaj znajduje się skrócenie - us (jako oznaczenie numeru porządkowego). 


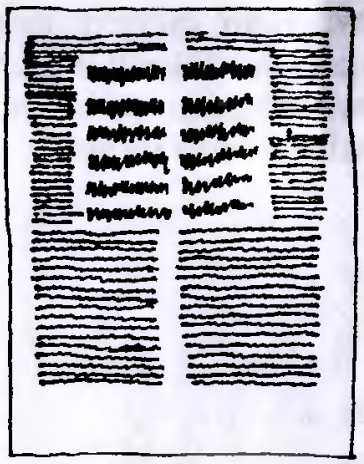

Fot. 10: Tekst główny $z$ komentarzem.

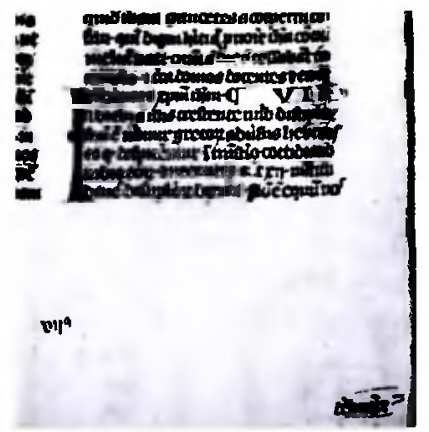

Fot. 11: Kustosz (rzymska VII ze skróceniem - us - lewy dolny róg) oraz reklamant na marginesie prawy dolny róg.

W opisie zwierciadła strony zamieszczamy również informacje o wypełnieniu przestrzeni powstałej na przyklad na końcu wiersza w sytuacji, gdy ostatnie słowo nie docierało do prawej granicy kolumny. Tym sposobem pisarze przezwyciężali horror vacui w okresie wczesnośredniowiecznym (typowe np. w pismach insularnych, ale również w gotyku, zob. fot. $4 \mathrm{~b}$ i 5). Ze względów estetycznych (być może również w celu uniknięcia późniejszego dodania tekstu) w ten sposób niekiedy wypełniane były również ostatnie wiersze dokumentów gotyckich (szczególnie w XIII i w pierwszej polowie XIV wieku). Natomiast niezwykłe odstępy między wierszami (czasami przerwane nadzwyczaj wydłużonymi górnymi kreskami) były jedną $\mathrm{z}$ podstawowych cech starszej minuskuły dyplomatycznej lub kurialnej. Przy opisie zwierciadła strony w dokumencie uwzględniamy podzial tekstu (jeżeli nie jest w jednym bloku): np. szczególne umieszczenie formuł subskrypcji i datacji. W opisie inskrypcji zwrócić należy uwagę na położenie w obrębie nośnika (układ tekstu napisu).

Podział wewnątrz słowa może tworzyć grupy liter. Może być to związanie punktów połączenia (tzn. ligatury fałszywe) lub ligatury we właściwym sensie tego słowa. „Ligatura" to połączenie dwóch lub więcej liter, które zmienia ksztalt co najmniej jednej z tych liter (najczęściej $c t$, et lub st). Złączenie liter (nexus 
litterarum) jest zjawiskiem, w którym część liter się pokrywa, ale żadna $\mathrm{z}$ nich nie zmienia swojej formy. Wpisanie (litterae inscriptae) to jedna litera wpisana w obręb drugiej (często np. w napisach nowożytnych). Gdy litery się przecinają, możemy mówić o literach nachodzących na siebie (littera intercisae).

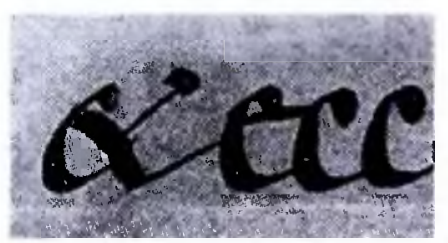

Fot. l2: Ligatura et.
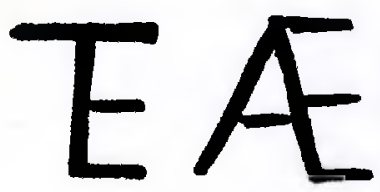

Fot. 13: Nexus litterarum

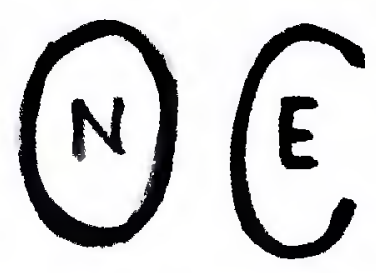

Fot. 14: Wpisanie liter (litterae inscriptae).
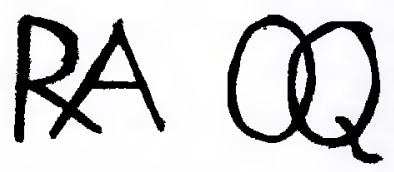

Fot. 15: Przecięcie liter (litterae intercisae).

W opisie konkretnych form pisma jako najważniejsze terminy możemy zdefiniować następujące pojęcia: pismo (jako synonimu można użyć terminu litera) jest wytworzone jedną lub więcej kreską. Kreska jest skutkiem ręki pisarskiej, a więc możemy tak określić w tekstach paleograficznych i malowanych napisach lub grafitti znak, który pozostawiło narzędzie pisarskie na materiale pisarskim, a w znaczeniu przenośnym tak możemy nazwać elementy zapisanych liter. Kreski są, ze względu na grubość, równe lub $z$ kontrastem linii włosowatych i grubych (różnorodność cienkich i grubych linii). 
Głównym pionowym elementem litery jest laska (tzn. prosta kreska pionowa - słow. driek, niem. Schaft). Stanowi zwykle jedną część liter „”, „i” lub części li-ter jak „A”, „D”, „E”, „a”, „g”, „m” itp. Jej górna część (wierzchołek) może być zakończona tępo, przez przyciśnięcie pióra (niem. Ansatz), wygięta do góry (np. przed zlamaniem) albo jest ( $\mathrm{u}$ góry $\mathrm{i} / \mathrm{lub} \mathrm{u}$ dołu) raz lub podwójnie złamana. W okresie późnego gotyku występuje rozszczepienie górnych lub dolnych części linii, które w okresie nowożytnym spowoduje rozszczepienie całych lasek.

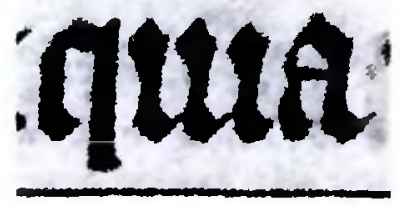

Fot. 16a: Podwójne złamanie lasek.

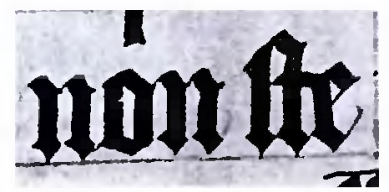

Fot. 16b: Podwójne zlamanie lasek (typ płomienisty typowy w późnym gotyku)
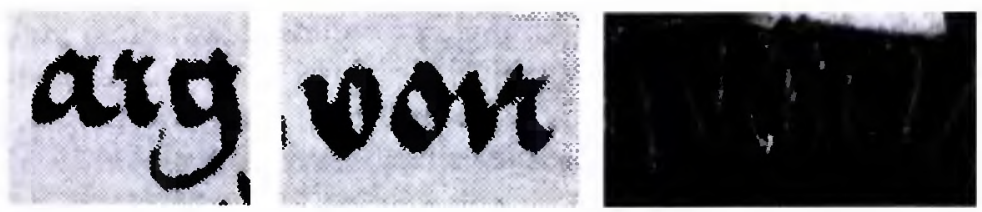

Fot. 17: Rozszczepienie wierzchołków lasek „.r” i „n” lub wierzchołków i podstaw „I” i „V”.

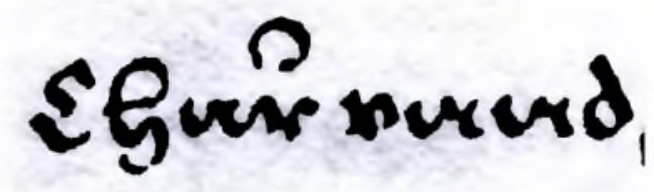

Fot. 18: W tekście Chur unnd występuje rozszczepienie lasek, najwyraźniejsze przy „r” $\mathrm{i}, \mathrm{n}$.

Na linii podstawowej laska może być zakończona tępo, ostro, nóżką (niem. mit Füßchen), odjęciem pióra (niem. mit Abstrich) albo złamaniem (Fot. 16a, b). W wypadku pism nowożytnych może być wygięta w łuk (niem. gebogen). W pismach epigraficznych występuje zakończenie za pomocą cierni (Fot. 24) albo szeryfów (bardziej wyrafinowane zakończenie ma cierń wytwarzany przy pomocy cyrkla, jak w klasycznej antycznej kapitale kaligraficznej). 


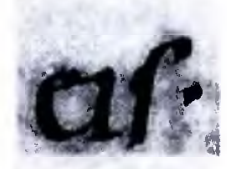

Fot. 19a: Dolne zakończenie lasek ze stopką (litera „i”).

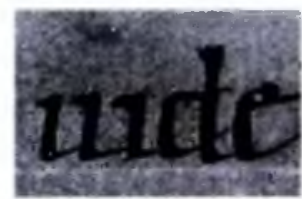

Fot. 19b: Dolne zakończenie lasek z odjęciem pióra.

\section{Sancte}

Fot. 19c: Dolne zakończenie lasek $\mathrm{z}$ wygięciem.

Charakterystyczną cechą pism kursywnych są zlączenia lasek lub zrosty (niem. Schaftverbindungen lub Bogenverbindungen) powstałe przez linie włosowate lub równe $\mathrm{w}$ wypadku pisma szybkiego i ciaglego, kiedy to pisarz nie odejmowal pióra od pisanej karty. Zlączenie linii może powodować tzw. efekt „zębów pily” (niem. Sägezähneeffekt; linie ze swoimi złączeniami mają ksztalt jakby zębów na pile - jest to zjawisko typowe w późnogotyckiej kursywie po ok. 1370/80, zwłaszcza po następujących po sobie literach „i”, „m”, ,n”, „u" - fot. 45). W okresie gotyckim charakterystyczną cechą jest „analogiczna organizacja linii” (niem. Angleichung der Schäfte), tzn. eliminacja połączeń linii, w konsekwencji następujące po sobie litery „„”, „u”, „m”, „n”, bez znajomości kontekstu, praktycznie nie pozwalają się odczytać.

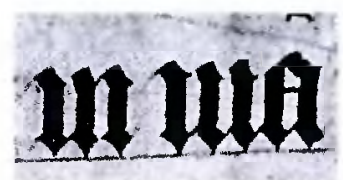

Fot. 20: Analogiczna organizacja lasek in via (typowa dla gotyku). 
Innym ważnym elementem pisma jest łuk (niem. Bogen) ${ }^{39}$. Stanowi on zwykle podstawowy okragły element liter „B”, „C”, „D”, „b”, „c”, „d”, „e”, „,", „h”, „o”, „p" itp. Charakterystycznym zjawiskiem w okresie wczesnego gotyku jest tzw. przyleganie luków (niem. Bogenberïhrungen), które w okresie gotyckim tworzyły złączenia łuków (Meyera) (niem. Bogenverbindungen). Pierwszy termin oznacza stykające się łuki dwóch sąsiadujących liter, drugi zaś ich połączenie. Tylko obecność tych spojeń luków (zasada Meyera) oznacza przejście minuskuły protogotyckiej w gotycka. Termin wprowadził przed ponad stu laty Wilhelm Meyer i od nazwiska tego badacza zjawisko to jest tak określane ${ }^{40}$. Glówny paleograf czeski J. Pražák określał je jako „lączenie liter"41, który to termin nie jest według nas precyzyjny. W pismach nowożytnych pojawia się zalamanie łuku lub załamanie $z$ pettelką. Obok laski i łuku, trzecim podstawowym elementem tworzącym literę jest kreska poprzeczna (belka) (niem. [Quer]Balken). Jest to główny poziomy element takich liter jak: „C”, „E”, „T”, „c”, „f”, „e”, „r”, „t”, „Z”.

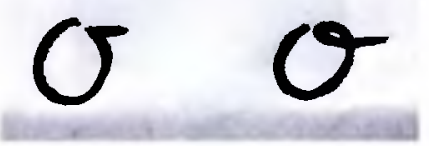

Fot. 21 Załamanie łuku (albo załamanie $z$ pętełka).

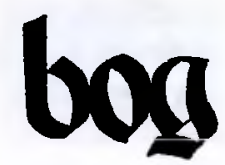

Fot. 22: W minuskule protogotyckiej typowe jest stykanie się łuków (brzuszków).
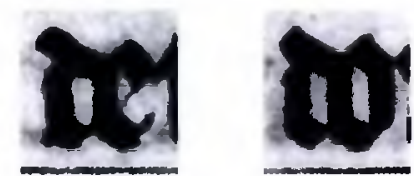

Fot. 23a. b: Cechą charakterystyczną pisma gotyckiego są zespolenia łuków (brzuszków).

\footnotetext{
${ }^{39}$ Wolimy doslowną kalkę $z$ języka niemieckiego, która może brzmieć: okrągły element $b, \boldsymbol{d}$ (dotychczas używany termin pochodzil od form antropomorficznych - brzuszek - zob. J. Sopko, $O$ najstarsich kódexoch... (s. 53,64) jak też przy g i p (glówka - hlavička - tamże, s. 55). Termin luczek (oblúcík) jest dobry do obu typów liter okrągłych, bez obciązenia semantycznego, współgra z terminem połączenie luków (oblúkové spojenie), akceptowany w innych krajach, jest w naszej opinii, trafniejszy i w pracy będziemy używać tego terminu.

${ }^{40}$ Wilhelm Meyer, Die Buchstaben-Verbindungen der sogenannten gotischen Schrift, w: Abhandlungen der Kgl. Gesellschaft der Wissenschaften zu Göttingen, phil.-hist. Klasse, N. F. 1. 6., Berlin 1897, s. 1-124.

${ }_{41}$ Jiří Pražák, Názvosloví knižních písiem v českých zemich II. 14.-15. století, „Studie o rukopisech”, 5:1966, s. 1-30; cytat - s. 10.
} 
W pismach majuskulnych możemy zasadniczo mówić o konkretnych formach kapitalnych lub uncjalnych. Formy kursywne (starsza kursywa rzymska lub kursywa cesarska) praktycznie nie były używane na naszym obszarze ${ }^{42}$. We wczesnym średniowieczu, w Europie środkowej, występują formy kapitały kwadratowej (np. „C”, „D”, „S” - pod wpływem znaków runicznych). W okresie gotyku wersaliki charakteryzują się synkretyzmem form kapitalnych i uncjalnych, który może prowadzić do powstania ksztaltów hybrydowych, jak pseudouncjalne „A" lub „T".

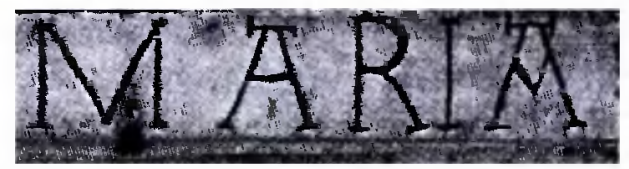

Fot. 24: „A” trapezowate (ostatnie ze zlamaną kreską poziomą). Litery są zakończone cierniami (nie

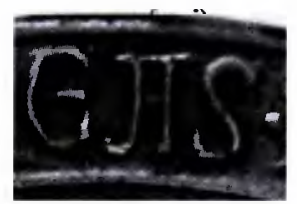

Fot. 25: „A" pseudouncjalne (w stowie ANDREAS)

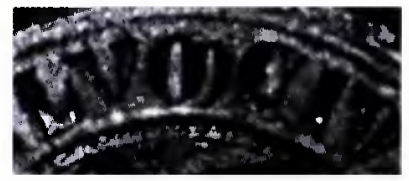

Fot. 26: „M" uncjalne zamknięte z lewej strony.

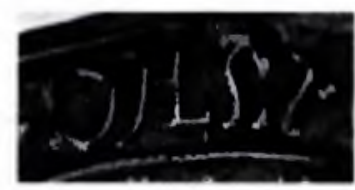

Fot. 27: „M" uncjalne, otwarte symetrycznie w slowie DALM(ACIE), ze znakiem skrócenia $w$ formie litery omega.

Typowym zjawiskiem (epigraficznej) majuskuły protogotyckiej jest zamykanie powierzchni zamkniętej literą (np. zamykanie łuków). Jest to szczególnie widoczne po połowie XIII i przed końcem XIV wieku. We wczesnych formach majuskulnych widoczna jest zaledwie tendencja do podobnego zamykania liter.

\footnotetext{
${ }^{42}$ Jedynym wyjątkiem jest napis starszą kursywą rzymską (por. ilustracja w: František Žák-Matyaszowszky, Antické nápisné pamiatky na území Slovenska, Nitra 2003, il. 134).
} 


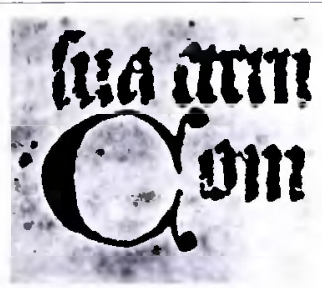

Fot. 28: Tendencja wczesnogotycka do zamykania obszaru zapisanego.

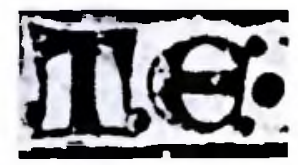

Fot. 29: Zamykanie obszaru pisania (TE) jest typowe dla majuskuły gotyckiej.

$\mathrm{Z}$ nowymi formami spotykamy się $\mathrm{w}$ późnym średniowieczu, kiedy to wraz z majuskułą wczesnohumanistyczną przychodzą „A" trapezowate, „E” dwubrzuszkowe, „M” „bizantyjskie” oraz „O” romboidalne. To pismo majuskulne cechuje się laskami „omegowatymi”, laskami z połowicznym nodusem lub z nodusem.

$$
\varepsilon, H, \backslash, 1,1
$$

Fot. 30: Typowe formy wezesnohumanistyczne (.E”, „M”, „O”, „I”, „I”, „I").

Wersaliki frakturowe charakteryzują się rozczłonkowaniem form (rozpad litery na większą liczbę jakby samoistnych oddzielnych części) i szczególnie ozdobnym rozmieszczeniem w formie wąsów (niem. termin roboczy to Elephantenrüssel).

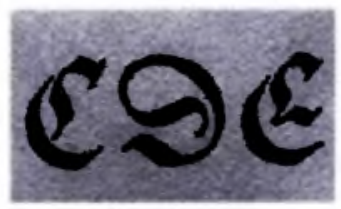

Fot. 31a: Rozczłonkowanie wersalików (w literach „C” i „E”).

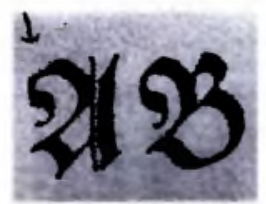

Fot. 31b: Typowe we frakturze wąsy.

Na naszym obszarze jako pismo tekstowe funkcjonowała przeważnie minuskuła. Opis niektórych form minuskulnych ułatwiają nam ogólnie przyjęte 
terminy międzynarodowe, jak skrzynkowe formy „a”, „o”, „p" czy okrągle „d”, "r", „s".

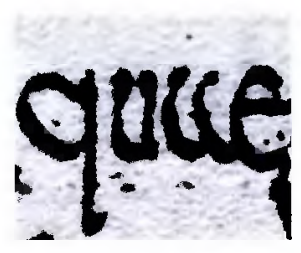

Fot. 32a: Litera „a" w formie podwojonego „c" (cc-a)

(typowa w okresie wczesnego średniowiecza, quae).

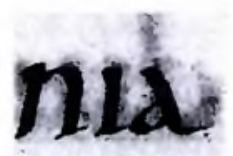

Fot. 32b: Jednołukowe „a” z laską pochyloną do lewej (ok. VIII-XI w.).

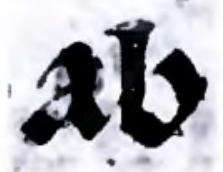

Fot. 32c: Jednołukowe „a” z laską wzniesioną

(od ok. XIl w. w formie gotyckiej w XIII-XV w.).

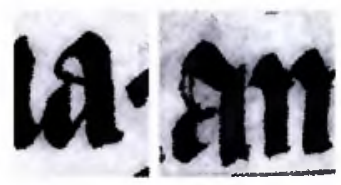

Fot. 32d: Litera „a” okrągłe zamknięte (XIV - pocz. XV w.) typu płomienistego (obrazek drugi)

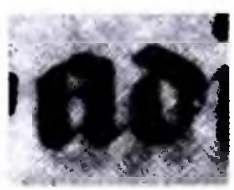

Fot. 32e: Litera „a" skrzynkowe (ok. ost. tercja XIV i 1 tercja XV w.).

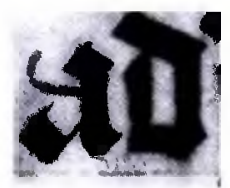

Fot. 32f: Litera „a” z załamanym górnym lukiem (ok. dwa ostatnie trzydziestolecia XV w.). 


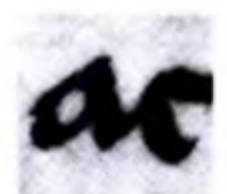

Fot. 32g: Litera „a” okrągłe ${ }^{43}$ (w Europie środk. od ok. XIV w.).

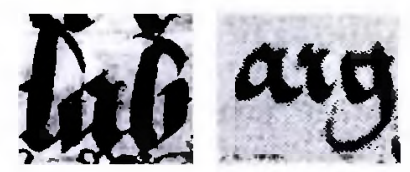

Fot. 32h: Litera „a" z rozszczepionym wierzchołkiem ( 2 i 3 tercja XV - 1 tercja XVI w.).

\section{maig}

Fot. 32i: Litera „a” $\mathrm{z}$ zalamaną laską (od pol. XVI do XIX w., naig).

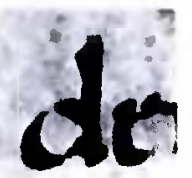

Fot. 33a: Litera „d” minuskulne.

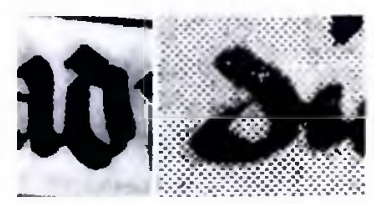

Fot. 33b: Litera „d" uncjalne"4.

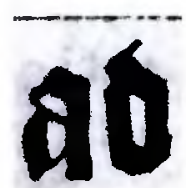

Fot. 33c: Litera ..d" uncjalne $z$ „kontra-kreską” na górnej lasce (charakterystyczne w końcu XIV i XV w.).

${ }^{43}$ Określenie „okrągłe $a$ ” jest bardziej odpowiednie niż często stosowane „a kursywne” - taką formę może mieć „a” w bastardzie gotyckiej, karolińskim piśmie glos itp.

${ }^{44} \mathrm{~J}$. Sopko ( $O$ najstaršich kódexoch..., s. 55) preferuje termin „d uncjalne" 


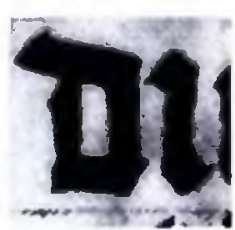

Fot. 33d: Litera „d” skrzynkowe (ok. 3 tercja XIV i 1 tercja XV w.).

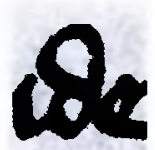

Fot. 33e: Litera „d" kursywne.

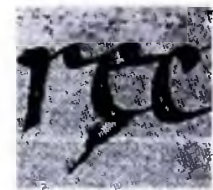

Fot. 34: Litera „e” caudata.

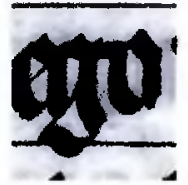

Fot. 35a: Litera "g" zlożone.

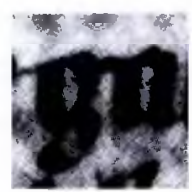

Fot. 35b: Uproszczone „g" minuskulne.

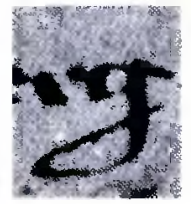

Fot. 35c: Litera "g" z pętelką.

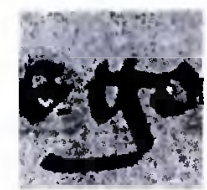

Fot. 35d: Litera "g" $z$ otwartą pętelką (g otwarte). 


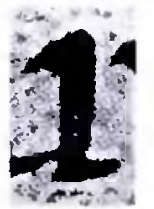

Fot. 36a: Litera „i"

(bez znaku identyfikacji - do ok. 2 pol. XII w. - później tylko z innymi formami $\imath$ ).

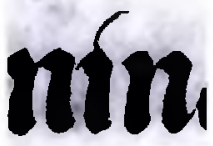

Fot. 36b: Litera „i" z kreską włosowatą (od ok. 2 pol. XII w. do czasów nowożytnych).

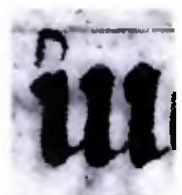

Fot. 36c: Litera „," $\mathrm{z}$ zaokrągloną kreską włosowatą (od ok. końca XIII w. do schylku średniowiecza).

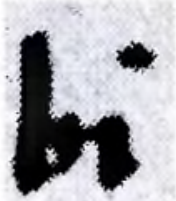

Fot. 36d: Litera „i” $\mathrm{z}$ kropką (od ok. 2 pol. XIV w.).

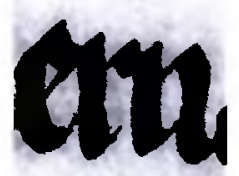

Fot. 37a: Litera „r" proste (ewentualnie $\mathbf{z}$ hakiem).

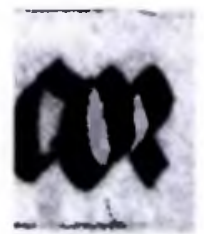

Fot. 37b: Litera „r" okraghte (od ok. XI w.). 

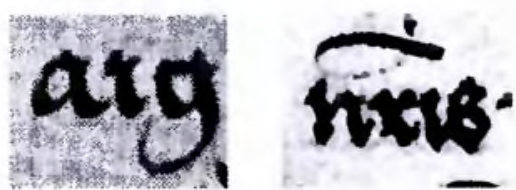

Fot. 37c: Litera "r" $z$ rozszczepionym wierzcholkiem (fot. pierwsza) lub nóżką (fot. druga) typowe w XV (rzadziej w XVD) w.

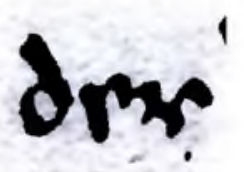

Fot. 37d: Litera „r” rozszczepione (kreska rozszczepiona od XVI w.).

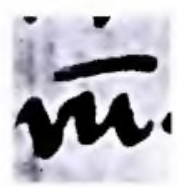

Fot. 37e: Litera „r" kursywne.

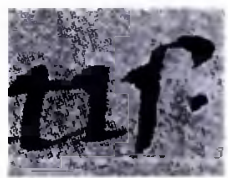

Fot. 38a: Litera „s" długie (czasami $z$ haczykiem).

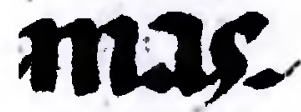

Fot. 38b: Wydłużona forma końcowego „s" (typowa w gotyku).

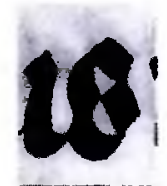

Fot. 38c: Litera „s” okrągle.

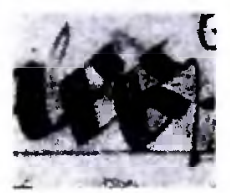

Fot. 38d: Litera „s" okragle zamknięte. 


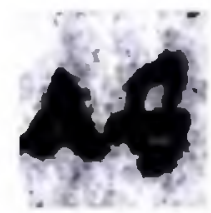

Fot. 38e: Litera "s" okragłe szóstkowe.

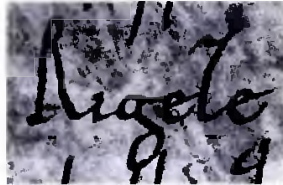

Fot. 39a: Litera „z” wysokie (Rigeze) typowe we wczesnym średniowieczu.

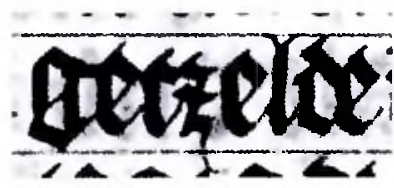

Fot. 39b: Litera „z" krótkie.

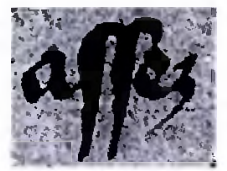

Fot. 39c: Litera „z" długie ${ }^{45}$.

Ze względu na konieczność oszczędzania drogich materiałów piśmiennych, a w niektórych pismach $z$ powodu oszczędzania czasu (np. w dyktacie) już w starożytności posługiwano się skróceniami i symbolami skróceń (abrewiacji). Typowymi średniowiecznymi sposobami skrócenia byly kontrakcja (skrócenie wyrazu przez usunięcie liter $z$ rdzenia wyrazu), suspensja (skrócenie przez usunięcie końca wyrazu) i abrewiacje za pomocą przyjętych znaków skróceńt ${ }^{46}$. Wśród najpowszechniejszych znaków skrócenia był titulus (w większości pozioma kreska oznaczająca, że wyraz jest skrócony) ${ }^{47}$. Kreska ta mogla mieć ksztalt prosty (w pismach książkowych lub w gotyku). W dokumentach czasów karolińskich i pokarolińskich znak ten występuje w postaci pólósemki, w kurii papieskiej w gotyku (i w Europie środkowej w XIII i na przelomie XV i XVI w.) występowal titulus w formie omega (fot. 27).

\footnotetext{
${ }^{45}$ Dobrą i konsekwentną terminologię wprowadza Karin Schneider (Paläographie und Handschriftenkunde für Germanisten, Tübingen 1999, s. 215-216).

${ }^{46}$ Adriano Capelli, Dizionario di abbreviature latine ed italiane, wyd. 6, Milano 1990, s. XI-LVI.

${ }^{47}$ Ch. Jacobi-Mirwald, Buchmalerei. Ihre Terminologie in der Kunstgeschichte, wyd. 2, Berlin 1997, s. 46.
} 
Skrócenia występują w postaci znaków $z$ wlasnym znaczeniem (kiedy mogły być odczytywane różnie - wg kontekstu) lub które powstaly jako stylizacja form (np. gotyckie skrócenie na -rum) i wreszcie jako substytut innego znaku zastępczego (np. gotyckie $e t)$. Najczęstsze formy skróceń to:

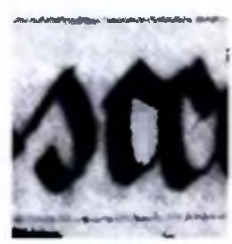

Fot. 40a: Starsza forma con- w formie lustrzanego odbicia „c”.

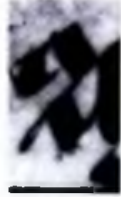

Fot. 40b: Mlodsza forma con-w ksztakcie arabskiej „2”.

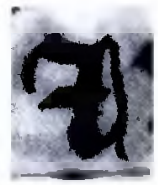

Fot. 41a: Tyrońskie et (w kształcie litery „z”; niekiedy przekreślone).

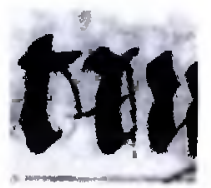

Fot. 41b: Spójnik et w kształcie litery „z”, ze skróconą kreską poprzeczną (belką).

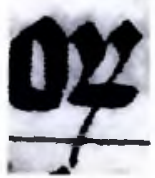

Fot. 42a: Proste-rum.

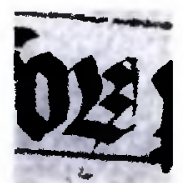

Fot. 42b: Złożone-rum.

Oprócz znaków liter i skróceń w tekście spotykamy grafemy oznaczające cyfry. Do XIV wieku w Europie środkowej występowały tylko cyfry rzymskie 
(zwykle w formie liter minuskulnych „i”, „v", „x”, ,l”, „c", „d”, w datacji dokumentów przeważaja wersaliki: „M”, „C”, „L”, „X”, „V”, „I"). Cyfry arabskie pojawiły się na Węgrzech za czasów panowania Ludwika Andegaweńskiego. W przeciwieństwie do form dzisiejszych, ksztalt cyfr byl inny, szczególnie w formie gotyckiej liczby „4” (półósemka) i „7” (podobna do daszku).

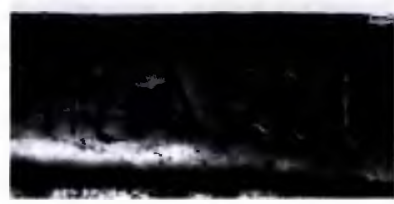

Fot. 43: Dwa odmienne od dzisiejszych formy cyfr: „7” i „4" (tekst: de(m) 74 ist).

Ogólny obraz pisma uzupelniają znaki pomocnicze, którym brak odpowiednika fonetycznego w języku. Dotyczy to w szczególności znaków interpunkcyjnych, rozdzielających, znaków skróceń, znaki tekstowokrytyczne i neumy. Już w średniowieczu Izydor z Sewilli, w swojej pracy encyklopedycznej, podjąl próbę systematyzacji tych znaków ${ }^{48}$.

Interpunkcja do końca średniowiecza nie zostala ujęta w sztywne ramy i dlatego możemy powiedzieć o znakach interpunkcyjnych, że nie były one jednakowo używane, lecz ich podstawowymi formami były kreska ukośna, kreska ukośna $z$ kropką, kropka i dwukropek. Znakiem, który ostrzegal czytelnika, od wczesnego średniowiecza, o przeniesieniu wyrazu do nowego wiersza, byl myślnik zwykle kreska włosowata na końcu wiersza prosta (często wychodząca jeszcze $z$ ostatniej litery w wierszu), podwójna lub zygzakowata.

Jednym ze znaków dzielących tekst jest alinea (znak paragrafu, majuskulne „C", pochodzące od oznaczenia głowy - caput), o którym Izydor $z$ Sewilli jeszcze nie wspominal, a który pojawia się w tekstach od XIII wieku. W napisach spotkamy się często $z$ separatorem (np. w ksztakcie kropki między wyrazami).
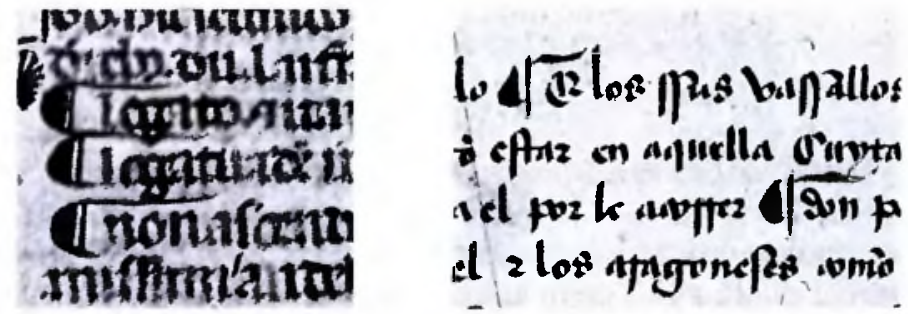

Fot. 44: Alinea albo paragraf.

${ }^{48}$ Isidor ze Sevilly, Etymologiae I-III, preložil D. Korte, Praha 2000, s. 98-105.

Z badań nad książką i księgozbiorami historycznymi, 3:2009 
Wśród znaków pomocniczych w rękopisach bratysławskich występują znaki tekstowokrytyczne (wg Izydora $z$ Sewilli notae sententiarum). Do tej grupy znaków należą: asteriscus (gwiazdka, oznaczająca miejsca, które są pominięte), obelus (kreska pozioma, oznaczajaca zbyteczne podwojenie albo złe przepisanie tekstu), obelus superne appunctatus (używany na oznaczenie miejsc, w których nie wiadomo, co ma być usunięte), asteriscus cum obelo (oznaczenie źle rozplanowanych wierszy), antigraphus cum puncto (oznacza miejsca, w których tłumaczenie ma inne znaczenie), antisigma (oznacza wymianę wierszy), antisigma cum puncto (wybór jednego $z$ dwóch wierszy), ceraunium (oznacza kilka niewłaściwie umieszczonych wierszy), cryphia (dolna część koła z kropką, oznaczająca niejasne i dyskusyjne miejsca), lemniscus (pionowa kreska między dwiema kropkami w miejscach, w których własnymi słowami wyjaśnione zostały fragmenty Biblii) i inne ${ }^{49}$.

$Z$ powyższymi znakami w rękopisach $z$ terenów Słowacji spotykamy się rzadko - najczęściej występującym znakiem jest bez wątpienia asterisk, którym pisarze zaznaczali zwykle uzupełnienia do tekstu podstawowego, przy czym oznaczano nim dopehnienie i miejsce w tekście głównym, gdzie komentarz ma być dodany. Wśród znaków tekstowokrytycznych możemy wskazać na rysunek dłoni, zwykle $z$ wyprostowanym palcem, kierującym do tego miejsca w tekście, na które czytelnik powinien zwrócić uwagę (nota bene). Jest to znak występujący stosunkowo często w rękopisach bratysławskich.

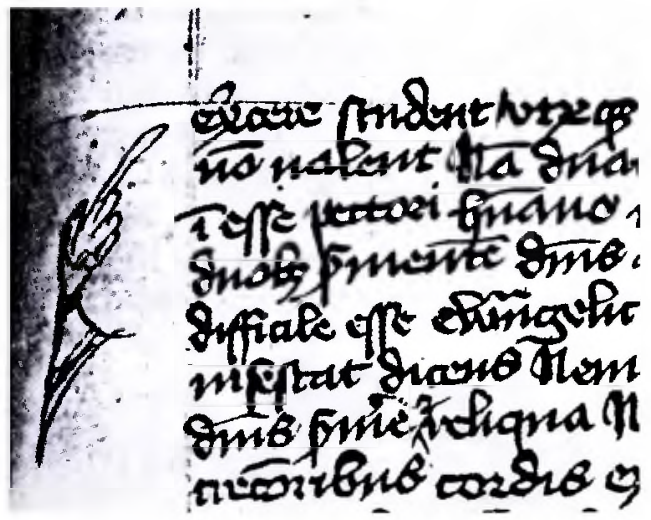

Fot. 45: Rączka w funkcji Nota bene i kursywa z efektem „zębów pily”.

Do grupy znaków tekstowokrytycznych należą niewątpliwie również znaki na uzupelnienia i poprawki. Takim znakiem jest wykropkowanie wyrazu (niem. Tilgung), które oznaczało, że słowo zostało błędnie zapisane (zwykle poprawke umieszczano powyżej lub na marginesie). W rękopisach $z$ biblioteki kapituły bratysławskiej często uzzywane jest np. „V” lub odwrócone „V”, oznaczające miejsce, w którym należy umieścić krótką wstawkę tekstową.

\footnotetext{
${ }^{49}$ Tamże; A. Capelli, Dizionario..., s. LI-LII. Obaj autorzy wprowadzają dalsze - mniej częste znaki.
} 


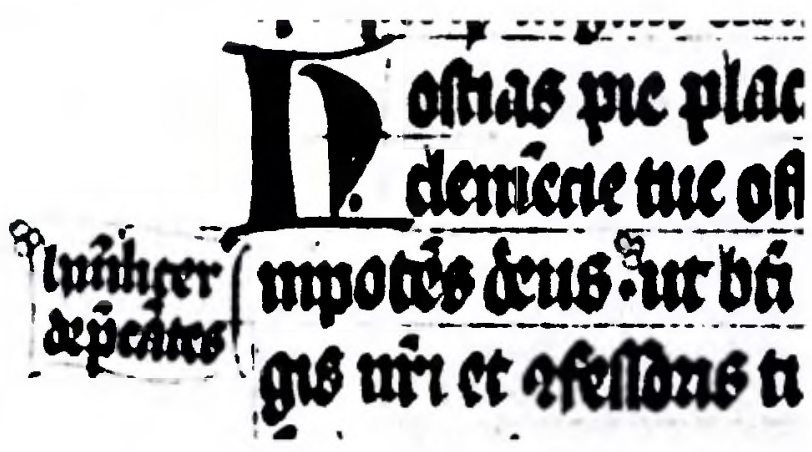

Fot. 46: Oznaczenie wtrętu w formie trojlistnej.

\section{Kryteria analizy pism historycznych}

W analizie pisma, której celem jest przyporządkowanie tekstu do stylu pisma, rodzaju i typu (i na tej podstawie datowanie i określenie proweniencji) i odpowiednio którego celem może być porównanie rąk pisarskich, konieczne jest postępowanie od nakreślenia ogólnego obrazu pisma aż do opisu pojedynczych form liter. O rozpoznaniu dwóch podobnych rąk (szczególnie w ramach jednego skryptorium lub kancelarii) często nie decydują różnice morfologiczne, ale ogólne wrażenie, jakie pismo „wywiera" na obserwatorze. Dlatego też trudno czasem odnaleźć pojęcia oddające całkowicie charakter ręki pisarskiej ${ }^{50}$. W celu bardziej obiektywnego określenia ogólnego wrażenia ręki pisarskiej Ettore Falconi zaproponował używanie trzech pojęć: dukt, modul i waga pis$\mathrm{ma}^{51}$. Największy nacisk polożył na analizę duktu. W jego pojęciu dukt jest „istota”, czyniącą dane pismo specyficznym. Według niego jest to „kwintesencja elementów, które są wspólne dla pisma lub całych zbiorów liter". Moduł rozumiał jako kategorię wyjaśniającą wielkość pisma (stosunek jego wysokości i szerokości). Kryterium wagi ma charakteryzować rozmiar przestrzeni zapisanej i niezapisanej, a wedle niej autor dzielil pisma na ciężkie i lekkie (paleografowie $w$ krajach niemieckojęzycznych posługują się terminami w analogicznym brzmieniu: „ciemne” lub ,jasne” pismo). Kategoria ta zależy od użytego narzędzia pisarskiego, materiału pisarskiego, atramentu, ale również od nacisku ręki pisarza i kąta, pod którym narzędzie przylożone zostalo do karty.

Od dawna już wszystkimi trzema kategoriami posługiwal się Jean Mallon ${ }^{52}$. Zasłużony paleograf czeski Jiř́ Pražák zaproponował wprowadzenie kategorii

\footnotetext{
${ }^{50}$ Termin ręka pisarska (pisárska nuka) jest odpowiedni dla typowego rękopisu samego pisarza, termin ręka pisarza (pisárova ruka) jest lepszy na oznaczenie rzeczywistej kończyny (np. przy opisie prowadzenia ręki po materiale piśmiennym).

${ }^{51}$ Ettore Falconi, Note di metodo sulla ricerca paleografica, Parma 1973. Najnowszy przegląd propozycji terminologicznych przedstawiają Armando Petrucci i Gudrun Brom (A. Petrucci, Die beschriebene Schrift, w: Methoden der Schriftbeschribung, ed. Peter Rück, Stuttgart 1999, s. 9-15; G. Brom, Neue Vorschläge zur paläographischen Schriftbeschreibung, tamże, s. 21-42).

52 Jean Mallon, Paléographie romaine, Madrid 1952, s. 22-23.
} 
„wrażenie ogólne” $\mathrm{i}$ „charakter pisma” (które mają wyjaśniać wzajemne relacje liter, słów i wierszy) ${ }^{53}$. W byłej czechosłowackiej terminologii pojęcie duktus zostało przyswojone jako charakterystyka pisma pod względem jego płynności i dynamiki kresek. Zgodnie $z$ tym pismo było oznaczone jako pismo $z$ duktem spokojnym łub pismo dynamiczne itp.

W reakcji na wątpliwą dokładność tych kryteriów inni paleografowie próbowali ustalić obiektywne i mierzalne kryteria i przybliżyć paleografię naukom ścisłym. Léon Gilissen, wychodząc $z$ prac Mallona, mierzył kąt pisma, stosunek modułu, za pomoca skomplikowanej definicji ustalał wage pisma, analizowal dukt, obserwował morfologię liter i styl. Przy kącie pisma, według Gilissena, wszystko jedno, czy paleograf mierzy kąt, który tworzyla ręka lub narzędzie pisarskie oraz karta, czy kąt między kreską włosowatą i grubą litery. Obie wielkości zależą od siebie wzajemnie. W kategorii modułu są dwie wielkości - moduł bezwzględny (wysokość/szerokość konkretnej litery) i moduł średni (średnia $z$ wielu pomiarów, $z$ której wyciąga się $t z w$. literę średnią). Modul średni opiera się na średniej wysokości wiersza. Stosunek między średnią wysokością litery i wiersza określa „wysokość pisma”, a stosunek między średnią szerokością litery i wiersza „gęstość pisma”. Kategoria duktu obejmuje ciąg kresek, za pomocą których pisarz tworzył literę. Jakkolwiek styl zawiera powtarzanie pewnych zjawisk, charakterystycznych w danym okresie lub w danym skryptorium, to morfologia zajmuje się wyjątkowością elementów form pisemnych tej samej ręki ${ }^{54}$. Wnioski Gilissena możemy uznać za zasadniczo ostatnią ważniejszą propozycję w dyskusji o kryteriach odróżniania rąk pisarskich. Ze względu na zlożoność i czasochłonność kryteria te się nie upowszechniły. W konkluzji warto stwierdzić, że jesteśmy zmuszeni polegać na subiektywnej ocenie badacza (tak jak np. w pracach $z$ historii sztuki) oraz że naszym zdaniem, fenomenu pisma nie da się wyjaśnić dokładnie. Wbrew Gilissenowi „obliczalne” średnie litery w rzeczywistości nie istnieją, i wreszcie - co jest największą słabością metod statystyczno-matematycznych ${ }^{55}$ - każdy rękopis jest zmienny w czasie. Pomimo jednak niemożności zastosowania metod ścisłych paleografia pozostaje nauką - nauką humanistyczną.

Nawet Jozef Mistrík w swojej Grafologii podkreśla, że przy opisie rękopisu należy postępować od cech ogólnych, jak „wykorzystanie przestrzeni, rozłożenie tekstu na stronie i całkowity układ graficzny, tzw. fasada tekstu. Nastepnie dokonuje się szczegółowego rozbioru poszczególnych znaków i ich najbliższego otoczenia" ${ }^{56}$. Podsumowując, proponujemy stosować odrębne kryteria, które można zaliczyć do dwóch grup - kryteria określające wrażenie ogólne i kryteria opisujące morfologię poszczególnych elementów pisma (nie liter). Jeśli

${ }^{53}$ J. Prażảk, Názvosloví.. I, s. 7.

${ }^{54}$ Léon Gilissen, L'expertise des écritures médiévales. Recherche d'un méthode avec application á un manuscrit du Xle siécle. Le Lectionaire de Lobbes (Codex Bruxellensis 18018), Gent 1973. $50)$.

${ }^{55}$ Ostatnio propozycje terminologiczne przedstawili Armando Petrucci i Gudrun Brom (zob. przyp.

${ }^{56}$ Jozef Mistrik, Grafológia. Synkritická analýza v modernej grafológii, Bratislava 1985, s. 140. 
postępujemy systematycznie od ogółu do detalu, opisujemy ogólny wygląd tekstu, zdania i stowa, grafemy i ich połączenia i wreszcie poszczególne gesty ręki pisarskiej $^{57}$.

$\mathrm{W}$ analizie możemy podzielić pismo według średniego użycia funkcjonalnego na książkowe, dokumentowe i epigraficzne. Następnie opisujemy światło tekstu, tj. stosunek obszaru zapisanego do obszaru między wierszami (w konsekwencji ciężkie/ciemne pismo albo lekkie/jasne pismo). Zwracamy uwage na przykład, czy jest wyraźne oddzielenie górnego i dolnego lub prawego i lewego marginesu użytego materiału (np. karty kodeksu lub dokumentu) od części zapisanej (przeciwnym przykładem jest pismo nałożone na krawędzi, jak to jest charakterystyczne w prostych dokumentach wegierskich XIII w.). W tekstach do X wieku należy zwrócić uwage, czy słowa są wyraźnie oddzielone. Dalszym kryterium w określeniu konkretnego pisma jest waga (gęstość) pisma (stosunek zapisanego i niezapisanego obszaru w ramach słowa, który mówi o nacisku ręki pisarskiej, szerokości jego gestów, zależnych od sposobu przycięcia pióra).

Ważna jest obserwacja dynamiki pisma (starsze pojęcie to dukt), którą możemy określić według prawidłowości w tworzeniu liter, według odstępów między nimi, według spokojnego lub przeciwnie, dynamicznego sposobu pisania. Nalézy zwrócić uwage na poziomy skłon pisma (rozmieszczenie wierszy - góra, dól, środek) oraz na pionowy skłon (kąt lasek lub górnych linii wobec linii podstawowej). Pismo charakteryzuje jego modul, tzn. stosunek wysokości i szerokości grafemów (ze względu na stosowane obecnie terminy zamiast symetryczny, szeroki lub wysoki moduł można stosować oznaczenie pisma ustrukturyzowanego lub pomyślanego do szerokości lub do wysokości ${ }^{58}$ ). Wreszcie ogólne cechy danego tekstu oddaje typ kaligraficzny użytego pisma (pismo kaligraficzne, proste lub pospieszne).

Od charakterystyki ogólnej przechodzimy w analizie paleograficznej do obserwacji form poszczególnych grafemów: morfologia form liter (i innych elementów pisma) podlega, tak jak $\mathrm{i}$ inne zjawiska estetyczne, częstym zmianom i modom. Jest obowiązkiem paleografa, aby poprzez swoje analizy ustalił, które litery najbardziej podlegają trendom mody i pomagają ująć poszczególne okresu. Logicznie rzecz biorąc, są to najzwyklejsze i najczęstsze formy (np. litery „a”, „o”, „e”, „m”, „n”, ,s", jak też niektóre skrócenia, które jednak zależą od użytego języka i konkretnego okresu historycznego). Przeciwnie formy złożone, składające się $z$ jak największej liczby kresek lub rzadkie (np. litera „f”, „g”, „x”, „z”, niektóre skrócenia lub wersaliki) mogą najbardziej pomóc w rozpoznaniu poszczególnych rąk pisarskich w konkretnym czasie. W tym celu należy właściwie określić wszystkie osobliwości ręki pisarskiej (wszelkie odstępstwa od kanonu danego typu pisma). Morfologię form najlepiej oddaje sposób tworzenia liter (budowa pisma za pomocą pojedynczych gestów, tj. duktus Gilissena.

Oprócz kryteriów charakteryzujących samo pismo, w dokładniejszym określeniu chronologii i geografii rękopisu konieczna jest naturalnie analiza kolej-

\footnotetext{
${ }^{57}$ Podobną strukturę cytuje bez podania źródła Ŝupšáková (Pisané písmo..., s. 120).

${ }^{58}$ Użyl J. Sopko ( $O$ najstarsich kódexoch...) s. 55, 64. Kategoria ta ze względów stylistycznych może być oddana innymi słowami: „pismo tej ręki ma charakter wertykalny“ (tamże, s. 64).
} 
nych elementów sztuki pisarskiej, jak formalne cechy piśmienne (typ materiału pisarskiego, rodzaj atramentu, wymiary karty, sposób wytworzenia ramek lub linii, zdobnictwo, notacja itp.). Kryteria te mogą stanowić uzupełnienie analizy treściowej i językowej zabytku piśmiennego, które są dalszymi ważnymi wskazówkami w interdyscyplinarnym ujęciu kultury piśmiennej.

W podsumowaniu należy stwierdzić, że w każdej prezentacji lub publikacji paleograf powinien przedstawiać material ilustracyjny, który słuchaczowi lub czytelnikowi najlepiej ukaże prezentowane zjawisko i często zastąpi nawet najbardziej skomplikowaną terminologię. Jednak podstawowa terminologia paleograficzna (podobnie jak heraldyczna, dyplomatyczna, demograficzna itp.) musi być częścią teoretycznego przygotowania każdego, kto ma ambicję profesjonalnie scharakteryzować każdy zapisany tekst historyczny.

Przełożył Jerzy Kaliszuk 